\title{
SZERKEZETI ELEMEK TÖNKREMENETELI ANALÍZISE
}

\author{
Sipkás Vivien \\ PhD hallgató, Miskolci Egyetem, Gép- Terméktervezési Intézet \\ 3515 Miskolc, Miskolc-Egyetemváros, e-mail: machsv@uni-miskolc.hu \\ Vadászné Bognár Gabriella \\ egyetemi tanár, Miskolci Egyetem, Gép- és Terméktervezési Intézet \\ 3515 Miskolc, Miskolc-Egyetemváros, e-mail: v.bognar.gabriella@uni-miskolc.hu
}

\begin{abstract}
Absztrakt
A cikk célja, hogy bemutassuk a faktoriális kisérlettervezés alkalmazását a vizsgált szerkezeti elemek élettartamának meghatározására irányuló kisérleteknél. Feltárjuk, hogy hogyan tudjuk a kísérlettervezés metodikáját felhasználva megvizsgálni a mikrokapcsolók élettartamát. Ez a módszer lehetővé teszi, hogy egy idöben vegyük figyelembe egyszerre több faktor hatását is. A teljes faktoriális kísérletterv szabályait követve meghatározzuk a faktorok összes lehetséges szintjének kombinációját, megvizsgáljuk, hogy melyik faktor milyen mértékben módositja az optimalizációs paraméter értékét, amely információk alapján a kísérletsorozat megtervezhetö.
\end{abstract}

Kulcsszavak: kísérlettervezés, válaszfüggvény, mikrokapcsoló, teljes faktoriális kísérletterv

\begin{abstract}
The aim of this paper is to introduce the application of factorial experimental design for the lifetime of the structural components tested. The application of the experimental design method into the lifetime of the micro switch's tests is shown. This method allows multiple factors to be examined simultaneously. Following the rules of the full factorial design, we determine all possible level combinations of factors, we investigate what extent the value of the optimization parameter has been modified by these factors and design the experiment tests accordingly.
\end{abstract}

Keywords: design of experiments, response function, micro switches, complete factorial experiment design

\section{Bevezetés}

A mikrokapcsolókat az iparban széles körben alkalmazzák, elsősorban elektromos berendezésekben automatikus vezérlés céljából. A mindennapi életben gyakran használunk olyan termékeket, melyek müködéséhez elengedhetetlen a mikrokapcsolók beépítése. Például az elektromos kéziszerszámokban, kertigépekben, különféle háztartási gépekben és jármüvekben egyaránt találkozhatunk különböző típusú és méretü kapcsolókkal.

A felhasználók megkövetelik a legmagasabb müszaki tartalommal bíró, legmegbízhatóbb, kifogástalan termékeket. Ezért a nagyobb meghízhatóság követelményei megkívánják a rendszerek, alkatrészek és anyagok tesztelését megbízhatóság szempontjából. Ennek megfelelően a mikrokapcsolók vizsgálatát is ilyen szempontok alapján kell elvégezni. 
A kutatásunk célja egy olyan élettartam-elemző módszert bemutatni, amely az egységek tesztelése során figyelembe veszi az elektromos kerti szerszámokban alkalmazott mikrokapcsolók speciális müködési feltételeit, tönkremeneteli folyamatait és vizsgálati igényeit.

Korábbi munkáink során már elemeztük és összegyüjtöttük azokat a lehetséges meghibásodásokat, amelyek használat közben előfordulhatnak a vizsgált mikrokapcsolóknál [11,12]. Ezen meghibásodások között a leggyakoribb tönkremeneteli forma a mikrokapcsolók érintkező felületeinek kopása, ill. beégése. A felületek károsodását több tényező is befolyásolhatja, ilyen például a hőmérséklet, a páratartalom és a kapcsolási idő. Ezek alapján megterveztük a mikrokapcsolókat vizsgáló tesztberendezést [12-14], melyen egyszerre négy termék tesztelhető, továbbá lehetőség van a kapcsolási idő és a páratartalom szintjének beállítására.

A vizsgálatok során feltárjuk azokat a müködési viszonyokat, amelyek a berendezés szokásos müködési terheléséhez képest nagyobb terhelést jelentenek, és összehasonlíthatjuk a más-más szinteken müködtetett termékek élettartam adatait. A berendezés kialakítását, müködését és a tesztek folyamatát korábban már ismertettük [13, 14]. A dolgozatunk célja, hogy a mérések eredményeiből a faktoriális kísérlettervezés szabályainak alkalmazásával a mikrokapcsolók élettartamára következtetéseket vonjunk le.

\section{Kétszintü kísérleti terv}

A statisztikai kísérlettervezés számos módszerét alapvetően három nagy csoportba sorolhatjuk: a faktoriális tervek, a válaszfelülettervek, valamint a négyzetes tervek.

A faktoriális tervek lehetővé teszik több faktor egyidejű vizsgálatát. A kísérletek számának csökkentése érdekében a vizsgált beállítások számát faktoronként általában kettőre maximalizálják. Ez az érték elegendő a faktorok jelentőségének kimutatásához és esetenként az optimális beállítási tartomány meghatározásához is. A faktoriális tervek kezelése egyszerü és logikus, éppen ezért az ipari gyakorlatban kiválóan és könnyedén tudják használni. Az utóbbi években az ipar előszeretettel alkalmazza az egyszerüsített módszereket, mint például Shainin-féle [1, 2, 7-10, 18] és a Taguchi-féle [2, 6-10, 17] faktoriális módszereket.

A válaszfelület-módszerek a jelleggörbe-mezők modellezésére és az összefüggések részletes vizsgálatára használatosak. A módszerek előnye, hogy az előre meghatározott kísérleti utasítások lehetővé teszik a jelleggörbe-mezők matematikai modelljének felépítését. Ilyen ismert módszer például a BoxWilson módszer is, amelyet a kísérleteink megtervezéséhez alkalmazni fogunk.

A négyzetes terveket kettőnél több beállítási lehetőséggel rendelkező faktor egyidejü elemzésére használhatjuk. A faktorok számát azonban korlátoznunk kell a könnyebb kezelhetőség érdekében. A négyzetes tervek csoportjába tartozik az úgynevezett Latin négyzet és a Youden négyzet módszer is [7].

Az általunk alkalmazott eljárásban a Box-Wilson módszer szabályai szerint egy kísérletsorozatban minden faktor egyszer az egyik, és egyszer a másik szintre lesz beállítva. Tehát minden faktornak csak két szintje lesz. A $k$ számú faktor összes lehetséges szintkombinációját megvalósító $N$ kísérleti beállítások száma az

$$
N=2 \cdot k
$$

összefüggéssel határozható meg.

A kísérletiterv összeállításánál a faktorok egyik szintjének jele +1 , másik szintjének jele pedig -1 lesz. Ebben az esetben nem számít, hogy az alsó, vagy a felső szintet jelöljük-e +1 -gyel illetve -1-gyel. Ezek a megadott szintek a kísérletek elvégzése során konkrét fizikai mennyiségeket jelölnek majd, annak függvényében, hogy az adott faktor milyen mennyiséget képvisel (lásd 1. táblázat) [3]. 
A kísérletet úgy kell megtervezni, hogy minden faktor ugyanannyiszor szerepeljen +1 szinten, mint -1 szinten, és a faktorkombinációk is egyforma mennyiségben jelenjenek meg +1 szinten, mint -1 szinten. Ezt kísérleti mátrix segítségével mutatjuk be [3].

1. táblázat. Kísérleti mátrix 2 faktor esetén

\begin{tabular}{|c|c|c|c|c|}
\hline $\begin{array}{c}\text { Kísérleti beállítás sor- } \\
\text { száma }(i)\end{array}$ & $x_{1}$ & $x_{2}$ & $x_{1} x_{2}$ & $\begin{array}{c}\text { Kísérleti eredmények } \\
(y)\end{array}$ \\
\hline 1 & -1 & -1 & +1 & $y_{1}$ \\
2 & +1 & -1 & -1 & $y_{2}$ \\
3 & -1 & +1 & -1 & $y_{3}$ \\
4 & +1 & +1 & +1 & $y_{4}$ \\
\hline
\end{tabular}

Az 1. táblázatban összefoglaltuk a kísérleti beállítások lehetséges eseteit. A faktorok beállítási szintjei a mátrix soraiban foglalnak helyet, míg a táblázat oszlopai a faktorok hatásának jellemzéséhez szükségesek. A táblázat oszlopainak kitöltéséhez az előjelváltogatás-módszert használtuk fel. Az első faktornál egyenként váltogattuk az elöjeleket, a második faktornál kettesével. A kereszthatás oszlopban $\left(x_{1} x_{2}\right)$ a kereszthatásban résztvevő faktorok oszlopainak összeszorzásával határozzuk meg az elöjeleket [3].

\section{Teljes faktoriális kísérleti terv}

A teljes faktoriális kísérleti terv olyan módszer, amelyben meghatározzuk a faktorok összes lehetséges szintkombinációját. Az ilyen kísérletet kétszintü, $2 k$ típusú kísérletnek nevezzük. A kísérletek megtervezése során öt alapvető követelményre kell figyelni.

A faktorokkal szemben támasztott követelmények [3-5]:

- irányíthatók legyenek,

- egyértelmüek legyenek,

- hatékonyak legyenek, azaz szignifikáns hatásuk legyen a kísérlet eredményére,

- ismert és korlátozott értékkészletük legyen,

- a faktor szintek beállíthatók legyenek.

\subsection{Faktorok és faktorszintek meghatározása}

Meg kell határoznunk a faktorokat és a faktorszinteket. A faktorok a folyamatot jelentősen befolyásoló körülmények, azaz paraméterek. A faktorszintek pedig a faktorok által felvehető értékek. Ezeket a faktorokat és faktorszinteket a 2. táblázatban foglaltuk össze.

Ha egy kísérletben minden faktor ugyanannyi szintet vehet fel, akkor a kísérletben az összes lehetséges faktorszintek száma:

$$
n=p \cdot k,
$$

ahol $n$ a kísérletek száma, $p$ egy-egy faktor szintjeinek a száma, $k$ pedig a faktorok számát jelöli. A mikrokapcsolók esetén a kísérletek száma 4 a (2) összefüggés alapján [3]. 
2. táblázat. Faktorok számának és szintjeinek meghatározása

\begin{tabular}{|l|l|}
\hline \multicolumn{1}{|c|}{ Faktorok száma $(\boldsymbol{k})$} & \multicolumn{1}{c|}{ Faktor szintek jelölése $(\boldsymbol{p})$} \\
\hline Kapcsoló típusok & D1, D2, K1, K2 \\
\hline 1 faktor: Kapcsolási idö & 2 szint: $0,25 \mathrm{~s}$ és $0,30 \mathrm{~s}$ \\
\hline 2 faktor: Relatív páratartalom & 2 szint: $60 \%$ és $80 \%$ \\
\hline
\end{tabular}

A 2. táblázatban foglaltuk össze a kísérleteinket befolyásoló tényezőket. Eszerint 2 faktorunk van különböző faktor szinteken a 4 kapcsoló típusra (D1, D2, K1,K2 jelöléssel), 2 kapcsolási idő (ST) és 2 páratartalom $(R H)$ szint, ez 16 tesztet jelent egy mintára. Minden tesztet 10-szer ismételünk minden egyes típusnál, így összesen 160 tönkrement mikrokapcsoló minta lesz, melyek alapján élettartam adatokat lehet meghatározni. Megjegyezzük, hogy általában a kísérletekben célszerúen legfeljebb 15 faktor lehet, és azok maximum 30 szintet vehetnek fel. A dolgozatban 4 tönkrement minta eredményeit mutatjuk be.

\subsection{Faktoriális kísérlettervezés interpolációs képletei}

Meg kívánjuk vizsgálni, hogy melyik faktor milyen mértékben módosítja az optimalizációs paraméter értékét, és majd ezek alapján lehet megtervezni a teljes kísérletet. A Box-Wilson módszer, más néven gradiens-módszer lényege, hogy egymás után végrehajtott egyszerü kísérletsorozatokkal megállapítható, hogy a faktor-szintek milyen irányú módosításával határozható meg az optimális beállítás.

A faktoriális kísérlettervezés módszere felhasználható olyan kísérletek tervezéséhez, melyek célja az interpolációs képletek szerkesztése vagy optimális feltételek, szélsőértékek keresése [5]. A faktorok jelölése általánosan az alábbi:

$$
x_{1}, x_{2}, x_{3} \ldots x_{N} .
$$

A függő változók természetes értékét pedig y jelöli a (4) jelü összefüggésnek megfelelően. A modell az $y$ optimalizációs paraméter és az $x_{1}$ és $x_{2}$ faktorok közötti függvénykapcsolat, amelynek általános alakja a $\varphi$ válaszfüggvény:

$$
y=\varphi\left(x_{1}, x_{2}\right) .
$$

Mivel az $n$-dimenziós térben egy-egy faktor irányában csak két adatunk van, így erre a két pontra csak egyenes fektethetö.

\subsubsection{Lineáris modell}

A mérési adatok alapján a lineáris modell általános alakja $N$ faktor esetén az (5) jelủ egyenlettel írható le:

$$
y=b_{0}+b_{1} \cdot x_{1}+b_{2} \cdot x_{2}+\ldots+b_{N} \cdot x_{N} .
$$

Az egyes faktorok hatásának változásánál elegendő a változás irányát és nagyságát megadnunk ahhoz, hogy a következő lépést megtervezzük. Az (5)-ös összefüggésbe feltüntettük a $b_{i}$ együtthatókat, melyeket a későbbiekben a mérési adatokból kívánunk meghatározni (lásd 4. fejezet).

$$
2^{N}=\sum_{l=1}^{N}\left(\begin{array}{l}
N \\
l
\end{array}\right) .
$$


A (6) összefüggésben $N$ a faktorok összes lehetséges szintkombinációját realizáló kísérleti beállítások számát jelöli, $l$ pedig a vizsgált hatások sorszáma.

Esetünkben az interakcióban szereplö kísérletek száma négy és két hatást kívánunk vizsgálni; ennek értelmében a (6) összefüggés az alábbi szerint írható:

$$
2^{N}=\sum_{l=1}^{N}\left(\begin{array}{l}
4 \\
2
\end{array}\right)=2^{4}=16
$$

\subsubsection{Polinom approximáció}

Sokszor nem megfelelő a kísérleti felületet lineáris modellel közelíteni, hiszen elfordulhat, hogy két faktor között kölcsönhatás van, azaz a két faktor egyidejű hatása nem ugyanolyan változást hoz létre az $y$ optimalizációs paraméteren, mintha a két faktor hatását külön-külön vizsgáljuk. Ekkor a lineáris kísérleti felület nem megfelelö. A nemlineáris kísérleti modell két faktor esetén az alábbiak szerint írható fel:

$$
\hat{\mathrm{y}}=b_{0}+b_{1} \cdot x_{1}+b_{2} \cdot x_{2}+b_{12} \cdot x_{1} \cdot x_{2} \text {. }
$$

\section{A b együtthatók meghatározása}

Az (5) és (8) egyenletekben szereplő $b$ együtthatók kiszámítása a mérési adatok alapján történik. Ezek meghatározzák a kísérleti felületet, vagyis az összes faktor együttes hatását. A $b$ együtthatókat az alábbi képlet felhasználásával számíthatjuk ki $N=4$ esetén:

$$
b_{i}=\frac{1}{4} \sum_{i=1}^{4} x_{j i} \cdot y_{i},(j=0,1,2) \quad \text { és } \quad b_{12}=\frac{1}{4} \sum_{i=1}^{4} x_{1 i} x_{2 i} \cdot y_{i},
$$

ahol $x_{j i}$ értékek pedig a transzformált faktorok értékeit jelölik.

A 3. táblázatban a módszer bemutatására egy $D 1$ jelölésủ mikrokapcsoló tesztelése során kapott eredményeket mutatjuk be. Az $y_{i}$ érték azt a kapcsolási számot jelöli, amelynél a kapcsoló tönkrement. A kiszámított $b_{0}, b_{1}, b_{2}$, és $b_{12}$ együtthatók értékeit a 3. táblázatban összesítettük. A kísérletünkben az $S T$ a kapcsolási időnek megfelelő transzformált faktor az $x_{1}$ és az $R H$ relatív páratartalomnak megfelelő az $x_{2}$.

3. táblázat. 22 típusú kétfaktoros teljes kísérleti mátrix a D1 mikrokapcsolóra

\begin{tabular}{|c|c|c|c|c|c|c|c|}
\hline \multirow{2}{*}{$\begin{array}{c}\text { Kísérleti } \\
\text { beállítás } \\
\text { sorszáma } \\
i\end{array}$} & $\begin{array}{c}\text { Faktor } \\
(S T) \\
i s]\end{array}$ & $\begin{array}{c}\text { Faktor } \\
(R H) \\
{[\%]}\end{array}$ & \multicolumn{4}{|c|}{ Transzformált faktorok } & $\begin{array}{c}\text { Kísérleti } \\
\text { eredmények } \\
(y)\end{array}$ \\
\cline { 4 - 8 } & & $x_{0}$ & $x_{1}$ & $x_{2}$ & $x_{1} x_{2}$ & \\
\hline 1 & 0,25 & 60 & +1 & -1 & -1 & +1 & $y_{1}=139034$ \\
2 & 0,30 & 60 & +1 & +1 & -1 & -1 & $y_{2}=168082$ \\
3 & 0,25 & 80 & +1 & -1 & +1 & -1 & $y_{3}=117241$ \\
4 & 0,30 & 80 & +1 & +1 & +1 & +1 & $y_{4}=141253$ \\
\hline & & & $b_{0}=141402,5$ & $b_{1}=-12155,5$ & $b_{2}=-13265$ & $b_{12}=1259$ & \\
\hline
\end{tabular}


Sipkás, V., Vadászné Bognár, G.

Szerkezeti elemek tönkremeneteli analízise

A válaszfüggvény a faktorok egymásra hatását figyelmen kívül hagyó (5) lineáris modellel a 3. táblázat adatai alapján az alábbiak szerint írható fel:

$$
y=141402,5-12155,5 \cdot x_{1}-13265 \cdot x_{2} .
$$

A kölcsönhatás figyelembevételével a (8) formula szerint a válaszfüggvény a nemlineáris modellel a következő:

$$
\hat{y}=141402,5-12155,5 \cdot x_{1}-13265 \cdot x_{2}+1259 \cdot x_{1} \cdot x_{2} .
$$

Hasonló eljárással a további három kapcsolóra is elóállíthatóak a lineáris és a nemlineáris válaszfüggvények, melyeket a 4-6. táblázatokban mutatunk be.

4. táblázat. 22 típusú kétfaktoros teljes kísérleti mátrix a D2 mikrokapcsolóra

\begin{tabular}{|c|c|c|c|c|c|c|c|}
\hline $\begin{array}{c}\text { Kísérleti } \\
\text { beállítás } \\
\text { sorszáma }\end{array}$ & $\begin{array}{c}\text { Faktor } \\
(S T) \\
i\end{array}$ & $\begin{array}{c}\text { Faktor } \\
(R H) \\
{[s]}\end{array}$ & \multicolumn{4}{|c|}{ Transzformált faktorok } & $\begin{array}{c}\text { Kísérleti } \\
\text { eredmények } \\
(y)\end{array}$ \\
\cline { 5 - 8 } & & $x_{0}$ & $x_{1}$ & $x_{2}$ & $x_{1} x_{2}$ & \\
\hline 1 & 0,25 & 60 & +1 & -1 & -1 & +1 & $y_{1}=205622$ \\
2 & 0,30 & 60 & +1 & +1 & -1 & -1 & $y_{2}=196031$ \\
3 & 0,25 & 80 & +1 & -1 & +1 & -1 & $y_{3}=146875$ \\
4 & 0,30 & 80 & +1 & +1 & +1 & +1 & $y_{4}=156876$ \\
\hline & & & $b_{0}=176351$ & $b_{1}=102,5$ & $b_{2}=24475,25$ & $b_{12}=4898$ & \\
\hline
\end{tabular}

A $D 2$ típusú mikrokapcsolóra:

lineáris válaszfüggvény $\quad y=176351-102,5 \cdot x_{1}-24475,2 \cdot x_{2}$

nemlineáris válaszfüggvény $\quad \hat{\mathrm{y}}=176351-102,5 \cdot x_{1}-24475,2 \cdot x_{2}+4898 \cdot x_{1} \cdot x_{2}$.

\begin{tabular}{|c|c|c|c|c|c|c|c|}
\hline \multirow{2}{*}{$\begin{array}{c}\text { Kísérleti } \\
\text { beállítás } \\
\text { sorszáma } \\
i\end{array}$} & \multirow{2}{*}{$\begin{array}{c}\text { Faktor } \\
(S T) \\
{[s]}\end{array}$} & \multirow{2}{*}{$\begin{array}{c}\text { Faktor } \\
(R H) \\
{[\%]}\end{array}$} & \multicolumn{4}{|c|}{ Transzformált faktorok } & \multirow{2}{*}{$\begin{array}{c}\text { Kísérleti } \\
\text { eredmények } \\
(y)\end{array}$} \\
\hline & & & $x_{0}$ & $x_{1}$ & $x_{2}$ & $x_{1} x_{2}$ & \\
\hline $\begin{array}{l}1 \\
2 \\
3 \\
4\end{array}$ & $\begin{array}{l}0,25 \\
0,30 \\
0,25 \\
0,30\end{array}$ & $\begin{array}{l}60 \\
60 \\
80 \\
80\end{array}$ & $\begin{array}{l}+1 \\
+1 \\
+1 \\
+1\end{array}$ & $\begin{array}{l}-1 \\
+1 \\
-1 \\
+1\end{array}$ & $\begin{array}{l}-1 \\
-1 \\
+1 \\
+1\end{array}$ & $\begin{array}{l}+1 \\
-1 \\
-1 \\
+1\end{array}$ & $\begin{array}{c}y_{1}=99140 \\
y_{2}=182428 \\
y_{3}=125789 \\
y_{4}=138965\end{array}$ \\
\hline & & & $b_{0}=136580,5$ & $b_{1}=24116$ & $b_{2}=-4203,5$ & $b_{12}=-17528$ & \\
\hline
\end{tabular}

5. táblázat. 22 típusú kétfaktoros teljes kísérleti mátrix a K1 mikrokapcsolóra 
Sipkás, V., Vadászné Bognár, G.

A $K 1$ típusú mikrokapcsolóra:

$$
\begin{array}{ll}
\text { lineáris válaszfüggvény } & y=136580,5+24116 \cdot x_{1}-4203,5 \cdot x_{2} \\
\text { nemlineáris válaszfüggvény } & \hat{y}=136580,5+24116 \cdot x_{1}-4203,5 \cdot x_{2}-17528 \cdot x_{1} \cdot x_{2} .
\end{array}
$$

\begin{tabular}{|c|c|c|c|c|c|c|c|}
\hline \multirow{2}{*}{$\begin{array}{c}\text { Kísérleti } \\
\text { beállítás } \\
\text { sorszáma } \\
i\end{array}$} & \multirow{2}{*}{$\begin{array}{c}\text { Faktor } \\
(S T) \\
{[s]}\end{array}$} & \multirow{2}{*}{$\begin{array}{c}\text { Faktor } \\
(R H) \\
{[\%]}\end{array}$} & \multicolumn{4}{|c|}{ Transzformált faktorok } & \multirow{2}{*}{$\begin{array}{c}\text { Kísérleti } \\
\text { eredmények } \\
(y)\end{array}$} \\
\hline & & & $x_{0}$ & $x_{1}$ & $x_{2}$ & $x_{1} x_{2}$ & \\
\hline $\begin{array}{l}1 \\
2 \\
3 \\
4\end{array}$ & $\begin{array}{l}0,25 \\
0,30 \\
0,25 \\
0,30\end{array}$ & $\begin{array}{l}60 \\
60 \\
80 \\
80\end{array}$ & $\begin{array}{l}+1 \\
+1 \\
+1 \\
+1\end{array}$ & $\begin{array}{l}-1 \\
+1 \\
-1 \\
+1\end{array}$ & $\begin{array}{l}-1 \\
-1 \\
+1 \\
+1\end{array}$ & $\begin{array}{l}+1 \\
-1 \\
-1 \\
+1\end{array}$ & $\begin{array}{l}y_{1}=154036 \\
y_{2}=212592 \\
y_{3}=119831 \\
y_{4}=126723\end{array}$ \\
\hline & & & $b_{0}=153295,5$ & $b_{1}=16362$ & $b_{2}=-30018,5$ & $b_{12}=-12916$ & \\
\hline
\end{tabular}

6. táblázat. 22 típusú kétfaktoros teljes kísérleti mátrix a K2 mikrokapcsolóra

A $K 2$ típusú mikrokapcsolóra:

$$
\begin{array}{ll}
\text { lineáris válaszfüggvény } & y=153295,5+16362 \cdot x_{1}-30018,5 \cdot x_{2} \\
\text { nemlineáris válaszfüggvény } & \hat{y}=153295,5+16362 \cdot x_{1}-30018,5 \cdot x_{2}-12916 \cdot x_{1} \cdot x_{2} .
\end{array}
$$

\section{A válaszfüggvény kísérleti modellje}

Két faktor esetén a lineáris válaszfüggvény térben ábrázolható, melyet az 1. ábra szemléltet a D1 kapcsoló esetére. Itt az $S T$ és $R H$ faktorok transzformált faktorai a vízszintes síkon találhatóak, míg az y optimalizációs paraméter értékei meghatározzák a válaszfüggvény felületét, amelynek legmagasabb pontja a keresett optimális beállítást jelzi. Itt kapjuk a legnagyobb élettartam-értéket. A válaszfüggvénynek most csak egy kis négyszögü darabját látjuk. Az ábrán látható, hogy a maximális kapcsolási számot teljesítő mikrokapcsoló esetén 168082 a tönkremeneteli ciklusszám, amelyet $S T=0,30 \mathrm{~s}$ kapcsolási idő és $60 \%$ relatív páratartalom beállítása mellett rögzítettünk. A 139034 tönkremeneteli ciklusszám $S T=0,25 \mathrm{~s}$ kapcsolási idő és $60 \%$ relatív páratartalmak beállításával adódott. A 141253 ciklusszám 0,30 $s$ kapcsolási idő és $80 \%$ páratartalom beállítással, míg a 117241 érték $0,25 s$ kapcsolási idő és $80 \%$ páratartalom beállítással jött létre. A 2. ábra a (11) összefüggéssel megadott nemlineáris válaszfüggvényt mutatja. Az 1. ábra négyszögfelületet, míg a 2. ábra egy nyeregfelületet ábrázol. 


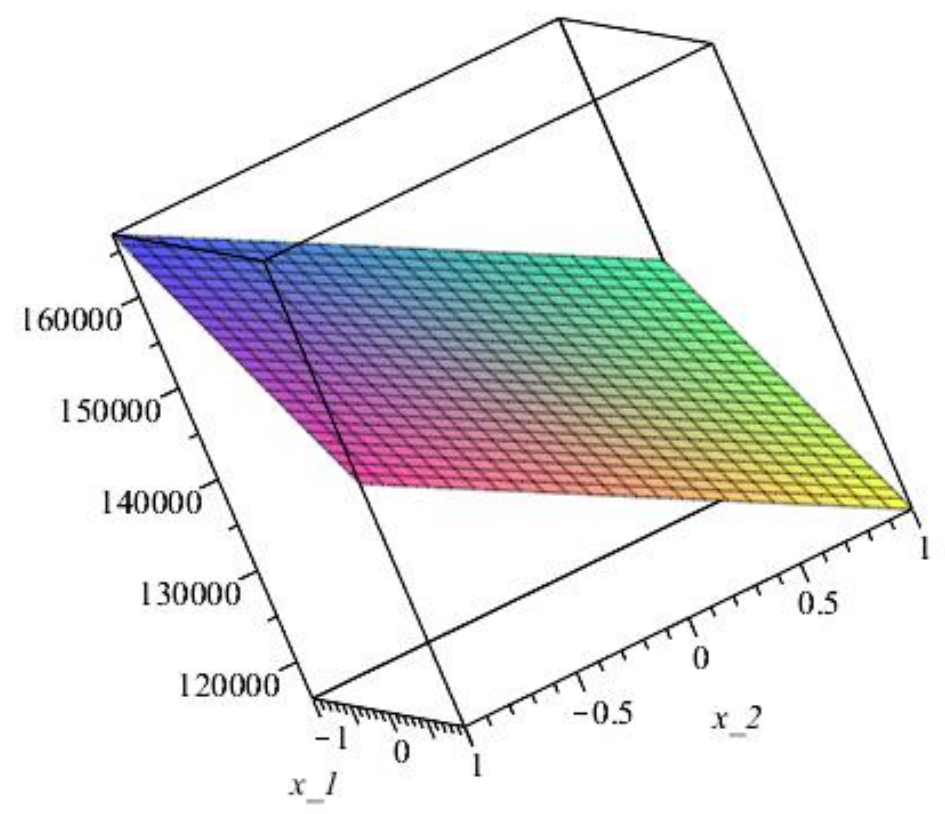

1. ábra. A válaszfüggvény két faktor esetén, lineáris modell alapján (D1 kapcsolóra)

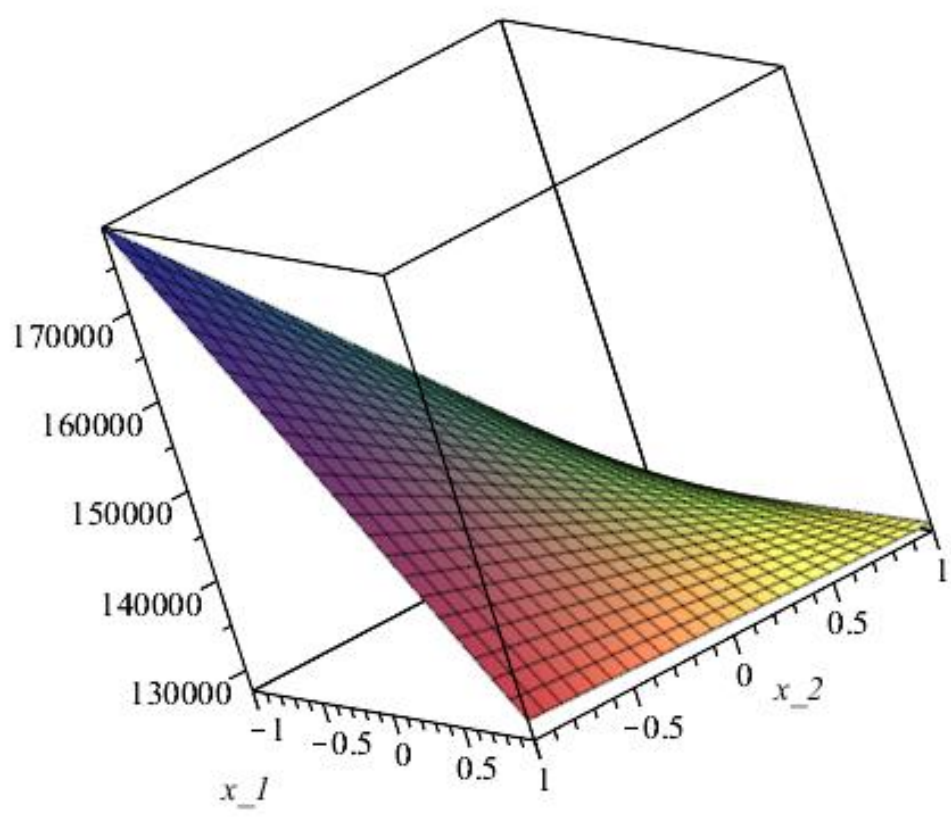

2. ábra. A válaszfüggvény két faktor esetén, nemlineáris modell alapján (D1 kapcsolóra) 
Ezek alapján megállapíthatjuk, hogy legjobb eredményeket akkor kapjuk, ha a $0,30 \mathrm{~s}$ kapcsolási idővel és $60 \%$-os páratartalom beállítással tesztelünk. Rosszabb eredményt pedig $0,25 \mathrm{~s}$ kapcsolási idő és $80 \%$ páratartalom megadásával. Tehát a vizsgált termékelemek élettartama csökken ha a páratartalmat növeljük, illetve ha a kapcsolási idő $0,30 s$-ról $0,25 s$-re csökken.

\section{6. Összefoglalás}

Cikkünkben bemutattuk a mikrokapcsolók tesztelésére alkalmazott kísérlettervezési módszerek adta lehetőségeket. A Box-Wilson módszert választva, meghatároztuk a faktorok összes lehetséges szintkombinációját és a kísérleti beállítások számát.

A kísérleti mátrixban összefoglaltuk az összes kísérleti lehetőséget és ábrázoltuk a válaszfelületeket. A kísérleti mátrix egyes oszlopai az egyes faktorok hatásának kiszámításához nyújtott segítséget. Meghatároztuk a kísérletünkben szereplő faktorokat és szinteket a vizsgált mikrokapcsoló-típusok, kapcsolási idő és páratartalom függvényében. Ezt követően pedig definiáltuk a $b_{i}$ együtthatók kiszámítására alkalmas összefüggéseket a kísérleti mátrix elemeivel. Ábrázoltuk a válaszfüggvényt lineáris és nemlineáris modell esetén a faktorok és a tönkremeneteli ciklusszámok megadásával.

A négy mikrokapcsolóra kapott eredmények összehasonlításakor megállapítható, hogy a legnagyobb élettartam $0,30 \mathrm{~s}$ kapcsolási idő és $60 \%$ páratartalom esetén adódik mind a négy kapcsoló típus esetén, és a legnagyobb élettartam ebben az esetben a $K 2$ típus esteén 212592 kapcsolás. A legkisebb élettartamot a $D 1$ típus esetén $0,25 \mathrm{~s}$ kapcsolási idő és $80 \%$ páratartalom mellett tapasztaltuk, ennél a kapcsolónál 117241 a kapcsolások száma.

A kutatásunk későbbi szakaszában jelentősen több teszteredményre kívánjuk megadni ezen együtthatókat és ábrázolni a válaszfelületeket, ilyen módon biztosítani a kísérleti eredmények megbízhatóságát.

\section{Köszönetnyilvánítás}

A cikkben ismertetett kutatómunka az Innovációs és Technológiai Minisztérium ÚNKP-19-3. kódszámú Új Nemzeti Kiválóság Programjának szakmai támogatásával készült.

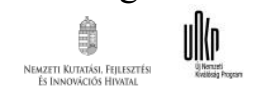

\section{Irodalom}

[1] Verma, A. K., Srividya, A., Mannikar, A. V., Pankhawala, V. A., Rathanraj, K. J.: Shainin method: edge over other DOE techniques, 2004 IEEE International Engineering Management Conference, Singapure, ISBN 0-7803-8519-5

[2] Aksu, B., Baynal, K.: Shainin and Taguchi methods and their comparison on an application, Gediz Univesity, Izmir, $1^{\text {st }}$ International Symosium on Computing in Science \& Engineering (2010) pp.801-809.

[3] Finszter, F., Aradi, P., Czmerk, A., Németh, Z., Wenzelné Gerőfy K., Halmai, A.: Jármüipari tesztelés és jóváhagyás (Letöltés dátuma:2020.02.21.)

[4] Fridrik, L., Csóka, J., Maros, Zs., Orosz L.: Faktoriális kísérlettervezés I., Nehézipari Müszaki Egyetem, Gépészmérnöki Kar, Miskolc (1988)

[5] Fridrik, L.: Faktoriális kisérlet-tervezés, oktatási segédlet, Nehézipari Müszaki Egyetem, Gépészmérnöki Kar, Miskolc (1979) 
[6] Jiju, A., Frenie Jiju, A.: Teaching the Taguchi method to industrial engineers, 50 No.4 (2001) pp.141-149. ISSN 0043-8022 https://doi.org/10.1108/00438020110391873

[7] Johanyák, Zs.: Bevezetés a kísérletmódszertanba, Kecskeméti Főiskola, Kecskemét, 2002.

[8] Kemény, S., Deák, A.: Kisérletek tervezése és értékelése, Müszaki Könyvkiadó, 2000

[9] Otto, K. N., Antonson, E. K.: Extension to the Taguchi method of product design, Engineering Design, Research Laboratory, Division of Engineering and Applied Science, California Institute of Technology (1991) pp.1-26.

[10] Tanco, M., Viles, E., Pozueta, L.: Comparing different approaches for design of experiments (DoE), Advances in Electrical Engineering and Computational Science (2019) pp. 611-621. https://doi.org/10.1007/978-90-481-2311-7_52

[11] Sipkás, V., Vadászné Bognár, G.: Mikrokapcsolók Weibull-eloszlásán alapuló gyorsitott élettartam vizsgálatok, Doktoranduszok Fóruma, Miskolci Egyetem, Gépészmérnöki és Informatikai kar (2018) pp.105-110. ISBN 978-963-358-166-7

[12] Sipkás, V., Vadászné Bognár, G.: Kerti gépekben alkalmazott mikrokapcsolók élettartam adatainak vizsgálata, Multidiszciplináris Tudományok, 9 No.2 (2019) pp. 90-95. https://doi.org/10.35925/j.multi.2019.2.13

[13] Sipkás, V., Vadászné Bognár, G.: Testing accelerated life data of micro switches, Design of Machines and Structures, 9 No.2 (2019), pp. 44-50. ISSN 1785-6892 https://doi.org/10.35925/j.multi.2019.2.13

[14] Sipkás, V., Vadászné Bognár, G.: Mikrokapcsolók élettartam vizsgálatának kérdései, XXVII. Nemzetközi Gépészeti Konferencia (2019) pp. 476-479. ISSN 2068-1267

[16] Sipkás, V., Vadászné Bognár, G.: Methods for accelerated life testing of micro switches in vehicles, GÉP folyóirat, 71 No.3-4 (2020), pp.72-75. ISSN 0016-8572

[17] Veličković, S., Stojanović, B., Babić, M., Vencl, A., Bobić, I., Vadászné Bognár, G., Vučetić, F.: Parametric optimazation of the aluminium nanocompozites wear rate, Journal of the Brazilian Society of Mechanical Sciences and Engineering, 41 No.1 (2019) pp.1-10. https://doi.org/10.1007/s40430-018-1531-8

[18] Sharma, S., Chetiya, A. R.: Simplifying the six sigma toolbox through application of Shainin DOE techniques, 34 No.1 (2019) pp. 13-30. https://doi.org/10.1177/0256090920090102 